\title{
HUBUNGAN ANTARA SIKAP TERHADAP PASIEN PENYAKIT JIWA DENGAN PERILAKU AGRESIF PERAWAT PASIEN PENYAKIT JIWA
}

\author{
Elok Faiqoh ${ }^{1 *}$ dan Falasifatul Falah ${ }^{* *}$ \\ ${ }^{1)}$ Fakultas Psikologi Universitas Islam Sultan Agung \\ ${ }^{*}$ E-mail: Ellfaee@gmail.com \\ ${ }^{* *}$ E-mail: falasifatul.falah@ gmail.com
}

\begin{abstract}
Abstrak
Tujuan dari penelitian ini adalah menguji korelasi antara sikap perawat terhadap pasien penyakit jiwa dengan perilaku agresif perawat pasien penyakit jiwa. Sampel penelitian adalah 75 orang perawat di Rumah Sakit Jiwa Prof Dr Soeroyo Magelang, Jawa Tengah, berdasarkan teknik pengambilan sample cluster random. Data diambil dengan skala perilaku agresif perawat pasien penyakit jiwa serta skala sikap terhadap pasien penyakit jiwa. Berdasarkan analisis data yang menggunakan teknik korelasi Product Moment, korelasi antara sikap perawat terhadap pasien penyakit jiwa dengan perilaku agresif perawat pasien penyakit jiwa adalah $r_{x y}=-0,508$ dengan signifikasi $0,000(p \varangle 0,01)$, menunjukkan adanya hubungan negatif yang sangat signifikan antara kedua variable tersebut.
\end{abstract}

Kata kunci: perilaku agresif, sikap terhadap pasien penyakit jiwa, perawat

\section{THE RELATIONSHIP BETWEEN NURSE'S ATTITUDE TOWARDS MENTAL-ILNESS PATIENTS AND AGGRESSIVE BEHAVIOUR OF NURSE WHO LOOK AFTER MENTAL-ILLNESS PATIENTS}

\begin{abstract}
This study was purposed to examine the relationship between nurse's attitude towards mental-illness patients and aggressive behaviour of nurse who look after mental-illness patients. Samples of study were 75 nurse in Prof Dr Soeroyo Mental Hospital Magelang, Central Java, based on cluster random sampling. Data was collected using aggressive behaviour scale and attitude towards mental-illness patients scale. Based on data analysis employing Product Moment correlation technique, it was found that correlation between nurse's attitude towards mental-illness patients and aggressive behaviour of nurse who look after mental-illness patients was $r_{x y}=-0,508$ while significance $0,000(p \varangle 0,01)$, showed that there was a very-significant negative correlation between these two variables.
\end{abstract}

Keywords: aggressive behaviour, attitude towards mental-illness patients, nurse

\section{Pendahuluan}

Merawat pasien dengan gangguan jiwa tentu berbeda dengan merawat pasien dengan gangguan fisik. Menangani pasien penyakit jiwa membutuhkan kesabaran dan ketelatenan yang tinggi karena karakteristik pasien penyakit jiwa yang unik, yaitu antara lain sulit diajak berkomunikasi, menarik diri, atau bahkan cenderung agresif. Nuradi (Praditia, 2008) mengatakan bahwa perilaku pasien penyakit jiwa yang sulit diprediksi dan berbahaya juga 
menuntut perawat pasien penyakit jiwa untuk lebih hati-hati dan waspada dalam memberikan perawatan. Kondisi mental serta sikap pasien penyakit jiwa yang labil juga memaksa perawat pasien penyakit jiwa untuk bersikap sabar dalam melakukan berbagai macam peranan untuk mengetahui apa yang dibutuhkan oleh pasien penyakit jiwa.

Wajar apabila seorang perawat jiwa mengalami stres ketika menjalani pekerjaannya. Stres yang dialami perawat terkait dengan beban pekerjaannya yang cukup berat Setiap hari perawat dihadapkan pasien-pasien penyakit jiwa yang mempunyai karakteristik yang berbeda dengan pasien biasa, antara lain sulit diajak berkomunikasi, sulit diatur, bahkan cenderung agresif. Perawat dituntut untuk selalu siaga ketika berhadapan dengan para pasien penyakit jiwa. Apabila seorang perawat kurang mampu mengontrol emosinya ketika berhadapan dengan pasien penyakit jiwa, maka dapat terjadi perilaku antisosial, salah satunya adalah perilaku agresif. Indriasari (2007) mengemukakan bahwa seseorang dapat berperilaku agresif ketika mereka berada dalam kondisi diancam atau tak aman bagi mereka.

Dawkins, dkk (Abraham, C dan Shanley, 1997) mengemukakan bahwa salah satu stressor pada perawat pasien penyakit jiwa adalah karakteristik pasien penyakit jiwa yang negatif seperti sulit diajak berkomunikasi, agresif, dan lain-lain. Keadaan dimana tekanan-tekanan pekerjan lebih berat karena setiap hari mengurus dan merawat pasien penyakit jiwa mengharuskan perawat pasien penyakit jiwa untuk mampu mengendalikan dan bertindak sesuai dengan tata cara perawatan sehingga tidak membahayakan diri dan pasien. Keadaan yang rentan dapat menyebabkan stres tersebut juga dapat menyebabkan individu menjadi kurang dapat mengontrol diri dan tingkah lakunya. Keadaan ini dapat menyebabkan individu melakukan tindakan-tindakan yang disebut perilaku antisosial, termasuk perilaku agresif. Kenyataannya sering dijumpai perawat rumah sakit yang kurang bertanggung jawab dalam bekerja dan melakukan tindakan agresif baik melalui fisik atau verbal (lisan) terhadap pasiennya.

Wawancara yang dilaukan peneliti pada tanggal 10 Oktober 2008 terhadap seorang mahasiswi akademi keperawatan $X$ yang sedang mengikuti magang kerja di Rumah Sakit Jiwa $X$ mengungkapkan bahwa ada indikasi perilaku agresif yang ditunjukkan oleh sebagian perawat pasien penyakit jiwa di rumah sakit tersebut. Mahasiswi tersebut menyatakan bahwa dia menyaksikan sebagian perawat pasien penyakit jiwa di Rumah Sakit Jiwa tersebut sering melakukan tindakan kekerasan terhadap pasien penyakit jiwa. Kekerasan yang dilakukan meliputi kekerasan fisik dan kekerasan verbal, contohnya membentak, memukul, menampar, dll. Hal tersebut dilakukan karena perawat pasien penyakit jiwa merasa kewalahan menghadapi pasien penyakit jiwa yang sulit diatur.

Perilaku perawat pasien penyakit jiwa yang cenderung agresif tersebut tentu bertentangan dengan kode etik keperawatan. Idealnya seorang perawat pasien penyakit jiwa diharapkan mempunyai sikap yang positif dan menerima pasien apa adanya sehingga dapat menciptakan suasana yang kondusif bagi pasien untuk sembuh dan berkembang, namun kenyataannya terdapat beberapa oknum perawat pasien penyakit jiwa yang melakukan tindakan yang merugikan pasien penyakit jiwa, seperti tindakan agresif. 
Berbagai penelitian mengenai perilaku agresif perawat pasien penyakit jiwa telah dilakukan. Salah satunya adalah penelitian yang dilakukan Indriasari, dkk (2007) yang meneliti tentang hubungan persepsi kekerasan yang dialami dengan kecenderungan perilaku agresif pada perawat pasien penyakit jiwa di RSJD Surakarta. Hasil penelitian menunjukkan bahwa terdapat hubungan positif yang sangat signifikan antara persepsi kekerasan yang dialami dengan kecenderungan perilaku agresif pada perawat pasien penyakit jiwa. Semakin tinggi persepsi kekerasan maka semakin tinggi pula kecenderungan berperilaku agresif.

Perilaku agresif adalah perilaku yang dimaksudkan untuk menyakiti orang lain, baik secara fisik (seperti menendang atau memukul) maupun psikis (seperti memaki atau mengancam) (Syafrika \& Tommy, 2004). Myers (dalam Syafrika \& Tommy, 2004) menyatakan bahwa perbuatan agresif adalah perilaku fisik atau lisan yang disengaja dengan maksud untuk menyakiti atau merugikan orang lain. Pendapat ini sejalan dengan pendapat Krahe (2005) yang mengatakan bahwa perilaku agresif harus dilakukan dengan niat menimbulkan akibat negatif terhadap targetnya, dan sebaliknya, menimbulkan harapan bahwa tindakan itu akan menghasilkan sesuatu. Perilaku dikategorikan agresivitas apabila bertujuan untuk melukai orang lain dan berusaha untuk melakukan tindakan agresi walaupun usahanya tidak berhasil.

Agresivitas yang dilakukan perawat secara tidak langsung dipengaruhi oleh sikapnya terhadap pasien. Nashori (Diana, 2007) mengemukakan bahwa salah satu faktor yang mempengaruhi agresivitas adalah sikap terhadap sumber agresi.

Sikap adalah suatu penilaian mengenai arah positif atau negatif, perasaan senang atau tidak senang, yang kemudian diikuti oleh kesediaan atau ketidaksediaan untuk bereaksi terhadap objek sikap (Permanadeli, 1988). Kimball Young (Dayakisni \& Hudaniah, 2001) menyatakan bahwa sikap merupakan suatu predisposisi mental untuk melakukan suatu tindakan, sedangkan Gerungan (Permanadeli, 1988) mengemukakan bahwa sikap masih berupa pandangan atau perasaan yang disertai kecenderungan untuk bertindak. Fishbein \& Ajzen (Dayakisni \& Hudaniah, 2001) menyebutkan bahwa sikap sebagai predisposisi yang dipelajari untuk merespon secara konsisten dalam cara tertentu untuk berkenaan dengan obyek tertentu.

Walgito (2001) mengemukakan bahwa terdapat tiga komponen yang membentuk sikap, yaitu: komponen kognitif (perceptual), komponen afektif (emosional), serta komponen konatif (kecenderungan perilaku). Permanadeli (1988) meyakini bahwa komponen afek mempunyai dua sifat, yaitu positif dan negatif. Individu yang mempunyai perasaan positif terhadap suatu obyek psikologis cenderung akan menyukai dan mempunyai sikap yang favourable terhadap obyek itu, sedangkan individu yang mempunyai sikap yang negatif terhadap suatu obyek psikologis dikatakan mempunyai sikap yang unfavourable terhadap obyek tersebut.

Hipotesis penelitian ini adalah ada hubungan antara sikap terhadap pasien penyakit jiwa dengan perilaku agresif pada perawat Rumah Sakit Jiwa Prof. dr. Soeroyo Magelang. Semakin positif sikap perawat terhadap pasien, maka perilaku agresifnya semakin rendah. Sebaliknya, semakin negatif sikap perawat terhadap pasien penyakit jiwa, maka perilaku agresifnya semakin tinggi. 


\section{Metode Penelitian}

Ada dua variabel dalam penelitian ini, yaitu perilaku agresif perawat pasien penyakit jiwa sebagai variabel tergantung, serta sikap terhadap pasien penyakit jiwa sebagai variabel bebas. Pengumpulan data dilakukan dengan menggunakan dua alat ukur psikologis, yaitu skala perilaku agresif perawat pasien penyakit jiwa serta skala sikap terhadap pasien penyakit jiwa. Uji coba kedua alat ukur tersebut dilaksanakan pada tanggal 29-30 Juni 2009 di Rumah Sakit Jiwa Prof. dr. Soeroyo Magelang. Subjek penelitian yang digunakan untuk uji coba adalah perawat pasien penyakit jiwa yang bekerja di instalasi rawat inap Rumah Sakit Jiwa Prof. dr. Soeroyo Magelang yang berjumlah 40 orang.

Skala perilaku agresif perawat pasien penyakit jiwa disusun oleh Elok Faiqoh berdasarkan aspek-aspek yang dikemukakan Albin \& Koeswara (Suryaningsih \& Anggraini, 2006), yaitu aspek pertahanan, aspek ketegasan, aspek perlawanan disiplin, aspek egosentris, aspek superioritas, aspek prasangka, serta aspek otoriter. Skala dibuat mengikuti aturan skala Likert. Rancangan awal skala ini terdiri atas 56 aitem, terdiri dari 28 aitem favorable dan 28 aitem unfavorable. Berdasarkan uji daya beda, diperoleh 30 aitem yang memiliki daya beda aitem tinggi, sedangkan sisanya 26 aitem memiliki daya beda rendah dengan taraf signifikansi 5 persen. Koefisien daya beda aitem untuk aitem yang tinggi pada alat ukur ini berkisar antara 0,302 - 0,736, dengan taraf signifikansi 5 persen terdapat 30 aitem yang memiliki daya beda tinggi dari 56 aitem yang ada. Estimasi reliabilitas alat ukur terhadap skala perilaku agresif perawat pasien penyakit jiwa dilakukan berdasarkan pada 30 aitem yang memiliki daya beda tinggi dengan menggunakan teknik alpha Cronbach, sehingga diperoleh koefisien reliabilitas alpha sebesar 0,843.

Skala sikap terhadap pasien penyakit jiwa juga disusun oleh Elok Faiqoh berdasarkan aspekaspek yang dikemukakan Walgito (2001), yaitu aspek kognitif, afektif dan konatif. Skala dibuat mengikuti aturan skala Likert. Rancangan awal skala ini terdiri atas 48 aitem, terdiri dari 24 aitem favorable dan 24 aitem unfavorable. Berdasarkan uji daya beda, diperoleh 45 aitem yang memiliki daya beda aitem tinggi, sedangkan sisanya tiga aitem memiliki daya beda rendah dengan taraf signifikansi 5 persen. Koefisien daya beda untuk aitem yang tinggi pada alat ukur ini berkisar antara 0,322 - 0,820, dengan taraf signifikansi 5 persen terdapat 45 aitem yang memiliki daya beda aitem tinggi dari 48 aitem yang ada. Estimasi reliabilitas pada alat ukur terhadap skala sikap terhadap pasiem penyakit jiwa dilakukan berdasarkan pada 45 aitem yang memiliki daya beda tinggi dengan menggunakan teknik reliabilitas alpha sebesar 0,956,.

Penelitian dilakukan di Rumah Sakit Jiwa Prof. dr. Soeroyo Magelang pada tanggal 30-31 Juli 2009. Kapasitas tempat tidur di Rumah Sakit Jiwa Prof. dr. Soeroyo Magelang saat penelitian dilakukan adalah 800 tempat tidur dengan jumlah bangunan 2,7 Ha yang terdiri dari bangsal rawat inap 26 unit, rawat jalan dan IGD masing-masing 1 unit. M asing-masing bangsal rata-rata terdapat 13 orang perawat.

Populasi pada penelitian ini adalah perawat pasien penyakit jiwa di Rumah Sakit Jiwa Prof. dr. Soeroyo Magelang yang berjumlah 435 orang. Sampel pada penelitian ini adalah perawat pasien penyakit jiwa di Rumah Sakit Jiwa Prof. dr. Soeroyo Magelang yang bekerja di instalasi rawat inap, sedangkan teknik pengambilan sampel dalam penelitian ini adalah Cluster Random 
Sampling, yaitu melakukan random terhadap bangsal-bangsal Rumah Sakit Jiwa Prof. Dr. Soeroyo Magelang.

Hasil analisis uji normalitas menunjukkan bahwa Z score untuk variabel perilaku agresif perawat pasien penyakit jiwa besarnya 0,904 dengan signifikansi 0,388 ( $p>0,05)$, sedangkan Zscore bagi variabel sikap terhadap pasien jiwa besarnya 0,797 dengan signifikansi 0,550 ( $p>$ $0,05)$. Hasil tersebut menunjukkan bahwa sebaran data kedua variabel memiliki distribusi normal.

Selanjutnya berdasarkan uji linearitas diperoleh $F_{\text {linier }}=25,34$ dengan $p=0,000(p<0,01$ yang menunjukkan bahwa distribusi skala perilaku agresif perawat pasien penyakit jiwa dan skala sikap terhadap pasien penyakit jiwa dalam penelitian ini adalah linier.

Hasil

Berdasarkan hasil analisis data dengan menggunakan teknik korelasi Product Moment Pearson diperoleh koefisien korelasi antara perilaku agresif dengan sikap terhadap pasien penyakit jiwa adalah negatif yang sangat signifikan, dengan $r_{x y}$ sebesar $-0,508$ dengan taraf signifikansi 0,000 ( $p<0,01$ ). Hal ini menunjukkan bahwa hipotesis yang diajukan dalam penelitian diterima, yaitu ada hubungan negatif yang sangat signifikan antara perilaku agresif dengan sikap terhadap pasien penyakit jiwa.

Besarnya sumbangan efektif dari variabel sikap terhadap pasien penyakit jiwa terhadap perilaku agresif perawat pasien penyakit jiwa adalah sebesar 25,806 persen sedangkan 74,194 persen yang lainnya dipengaruhi oleh variabel lain.

Deskripsi data dalam penelitian ini adalah sebagai berikut:

Skor skala perilaku agresif perawat pasien penyakit jiwa berdasarkan hasil penelitian (empirik) yaitu skor minimum sebesar 64, skor maksimum sebesar 116, mean sebesar 89,706, dan standar deviasi sebesar 137,533. Deskripsi skor skala perilaku agresif dapat dilihat pada tabel 1.

Tabel 1. Deskripsi Skor Skala Perilaku Agresif

\begin{tabular}{lll}
\hline & Empirik & Hipotetik \\
\hline Skor Minimun & 64 & 44 \\
Skor maksimum & 116 & 176 \\
Mean (M) & 89,706 & 110 \\
Standar Deviasi (SD) & 137,533 & 22 \\
\hline
\end{tabular}

Berdasarkan norma kategorisasi dengan distribusi normal kelompok subjek dalam penelitian ini maka dapat dilihat bahwa rentang skor subjek pada skala perilaku agresif perawat pasien penyakit jiwa berada dalam kategori 89,706 (berdasarkan mean hipotetik). Rentang skor skala perilaku agresif perawat pasien penyakit jiwa dapat dilihat pada gambar 1 . 


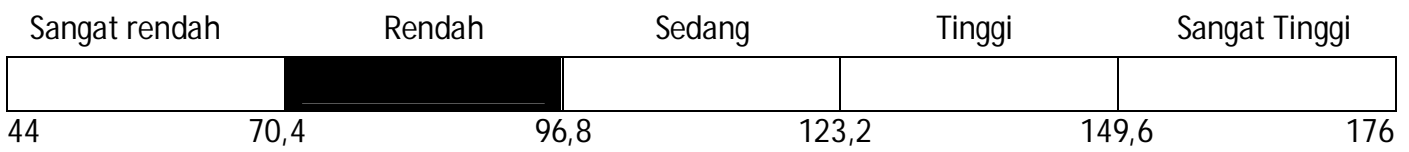

\section{Gambar 1. Rentang Skor Skala Perilaku Agresif Perawat Pasien Penyakit Jiwa (Berdasarkan Skor Empirik)}

Berdasarkan hasil tersebut dapat dilihat bahwa subjek yang berada dalam kategori sangat rendah berjumlah 4 orang dengan rentang skor 44 - 70,4. Subjek yang berada dalam kategorisasi rendah berjumlah 47 orang dengan rentang skor 70,4-96,8. Subjek yang berada dalam kategorisasi sedang berjumlah 24 orang dengan rentang skor 96,8 - 123,2. Kategorisasi skor subjek pada skala perilaku agresif dapat dilihat pada tabel 2 .

Tabel 2. Kategorisasi Skor Subjek (Skala Perilaku Agresif Perawat Pasien Penyakit Jiwa)

\begin{tabular}{lll}
\hline Rentang Skor & Jumlah Subjek & Kategorisasi \\
\hline $44-70,4$ & 4 & Sangat Rendah \\
$70,4-96,8$ & 47 & Rendah \\
$96,8-123,2$ & 24 & Sedang \\
$123,2-149,6$ & 0 & Tinggi \\
$149,6-176$ & 0 & Sangat Tinggi \\
\hline
\end{tabular}

Deskripsi skor perilaku agresif yang diperoleh berdasarkan hasil penelitian (empirik) yaitu skor minimum sebesar 114, skor maksimum sebesar 171, mean sebesar 137,533 dan standar deviasi sebesar 15,806. Deskripsi skor skala sikap terhadap pasien penyakit jiwa dapat dilihat pada tabel 3.

Tabel 3. Deskripsi Skor Skala Sikap terhadap Pasien Penyakit Jiwa (Berdasarkan Skor Hipotetik)

\begin{tabular}{lll}
\hline & Empirik & Hipotetik \\
\hline Skor Minimum & 114 & 45 \\
Skor Maksimum & 171 & 180 \\
Mean (M) & 137,533 & 112,5 \\
Standar Deviasi (SD) & 15,806 & 22,5 \\
\hline
\end{tabular}

Berdasarkan norma kategorisasi dengan distribusi normal kelompok subjek dalam penelitian ini maka dapat dilihat bahwa rentang skor subjek pada skala sikap terhadap pasien penyakit jiwa berada dalam kategori 137,533 (berdasarkan mean hipotetik). Rentang skor skala perilaku agresif dapat dilihat pada gambar 2. 


\begin{tabular}{|c|c|c|c|c|}
\hline Sangat Negatif & Negatif & Sedang & Positif & Sangat Positif \\
\hline$\overline{72}$ & & 126 & 15 & 180 \\
\hline
\end{tabular}

\section{Gambar 2. Rentang Skor Skala Sikap Terhadap Pasien Penyakit Jiwa (Berdasarkan Skor Empirik)}

Berdasarkan hasil tersebut dapat dilihat bahwa subjek yang berada dalam kategorisasi mempunyai sikap yang sangat positif terhadap pasien penyakit jiwa adalah 16 orang dengan rentang skor 153 - 180. Subjek yang berada dalam kategorisasi mempunyai sikap positif terhadap pasien penyakit jiwa berjumlah 37 orang dengan rentang skor 126 - 153. Subjek yang berada dalam kategorisasi sedang berjumlah 22 orang dengan rentang skor 99 - 126. Kategorisasi skor subjek pada skala sikap terhadap pasien penyakit jiwa dapat dilihat pada tabel 4.

Tabel 4. Kategori Skor Subjek (Skor Sikap Terhadap Pasien Penyakit Jiwa)

\begin{tabular}{lll}
\hline Rentang Skor & Jumlah Subjek & Kategorisasi \\
\hline $45-72$ & 0 & Sangat Negatif \\
$72-99$ & 0 & Negatif \\
$99-126$ & 22 & Sedang \\
$126-153$ & 37 & Positif \\
$153-180$ & 16 & Sangat Positif \\
\hline
\end{tabular}

\section{Pembahasan}

Berdasarkan hasil analisis data dengan teknik korelasi Product M oment diperoleh koefisien korelasi antara perilaku agresif perawat pasien penyakit jiwa dengan sikap terhadap pasien penyakit jiwa adalah negatif yang sangat signifikan, dengan $r_{x y}$ sebesar $-0,508$ dengan taraf signifikansi $0,000(p<0,01)$. Hal ini menunjukkan bahwa hipotesis yang diajukan dalam penelitian diterima, yaitu ada hubungan negatif yang sangat signifikan antara perilaku agresif dengan sikap terhadap pasien penyakit jiwa, yang berarti semakin positif sikap perawat pasien penyakit jiwa terhadap pasien penyakit jiwa, maka perilaku agresifnya semakin rendah. Sebaliknya semakin negatif sikap perawat pasien penyakit jiwa terhadap pasien penyakit jiwa maka perilaku agresifnya semakin tinggi.

Penelitian ini menunjukkan angka sumbangan efektif sebesar 25,806 persen. Nilai tersebut memiliki arti bahwa sikap terhadap pasien penyakit jiwa dapat mempengaruhi perilaku agresif sebesar 25, 806 persen, sisanya 74,194 persen dipengaruhi oleh faktor lain diluar variabel yang digunakan dalam penelitian, misalnya faktor biologis, kognitif, amarah, dan frustasi.

Hasil penelitian ini sesuai dengan teori yang dikemukakan Nashori (Diana, 2007) yang menyebutkan bahwa salah satu faktor yang mempengaruhi agresivitas adalah sikap terhadap sumber agresi, dalam penelitian ini sumber agresi yang dimaksud adalah pasien penyakit jiwa. Pasien dapat dikatakan sebagai sumber agresi karena dalam kesehariannya seorang perawat berhadapan langsung dengan pasien penyakit jiwa yang mempunyai kondisi emosional yang labil. 
Kondisi pasien yang labil membuat perawat harus ekstra sabar karena karakteristik pasien yang negatif, antara lain sulit diajak komunikasi, menarik diri, atau justru agresif. Seorang perawat pasien penyakit jiwa ketika mempunyai sikap positif terhadap pasien penyakit jiwa, maka ia akan cenderung menyenangi dan peduli dengan keadaan si pasien penyakit jiwa. Sebaliknya, ketika seorang perawat pasien penyakit jiwa mempunyai sikap yang negatif terhadap pasien penyakit jiwa, maka ia cenderung akan membenci dan menjauhinya.

Fakta di lapangan menunjukkan bahwa perilaku agresif perawat pasien penyakit jiwa di Rumah Sakit Jiwa Prof. dr. Soeroyo Magelang adalah rendah. Artinya bahwa perawat pasien penyakit jiwa di Rumah Sakit Jiwa Prof. dr. Soeroyo Magelang jarang melakukan perilaku kekerasan terhadap pasien penyakit jiwa. Hasil penelitian ini sejalan dengan hasil penelitian Indriasari, dkk (2007, h.109) yang meneliti tentang "Hubungan Persepsi Kekerasan yang Dialami dengan Kecenderungan Perilaku Agresif pada Perawat Pasien Penyakit Jiwa di RSJD Surakarta". Hasil penelitian menunjukkan bahwa ada hubungan positif yang sangat signifikan antara persepsi kekerasan yang dialami dengan kecenderungan perilaku agresif pada perawat pasien penyakit jiwa. Hasil penelitian juga menunjukkan bahwa kecenderungan perilaku agresif perawat pasien penyakit jiwa di RSJD Surakarta adalah rendah.

Rendahnya perilaku agresif ini kemungkinan disebabkan oleh beberapa hal, diantaranya: (1) adanya kesadaran akan tanggung jawab perawat pasien penyakit jiwa terhadap pasien penyakit jiwa, (2) faktor jenis kelamin, dan (3) faktor lama bekerja. Pertama, karena adanya kesadaran akan tanggung jawab perawat pasien penyakit jiwa terhadap pasien penyakit jiwa. Freedman, dkk (Indriasari, 2007) mengemukakan bahwa individu yang sadar akan tanggung jawabnya cenderung lebih berhati-hati dalam bertindak, termasuk dalam berperilaku agresif. $\mathrm{Hal}$ ini dikarenakan adanya perhitungan berat ringannya tanggung jawab yang harus dipikul apabila ia berperilaku agresif. Seorang perawat pasien penyakit jiwa akan dihadapkan pada berbagai masalah apabila ia berperilaku agresif terhadap pasien penyakit jiwa, baik permasalahan dengan pihak Rumah Sakit maupun dengan pihak keluarga pasien penyakit jiwa.

Kedua, karena faktor jenis kelamin. Menurut Epstein (Indriasari, 2007) laki-laki lebih agresif dari wanita. Hal ini terjadi akibat kontrol sosial yang cukup tinggi pada wanita dibandingkan pria. Berdasarkan data subjek penelitian, data menunjukkan bahwa dari 75 perawat, 46 perawat (61,33 persen) adalah perempuan dan 29 perawat (38,66 persen) adalah laki-laki. Faktor jenis kelamin berpengaruh pada hasil penelitian yang menunjukkan bahwa perilaku agresif perawat pasien penyakit jiwa di Rumah Sakit Jiwa Prof. dr. Soeroyo Magelang rendah karena sebagian besar subjek penelitian yang diambil adalah wanita.

Selanjutnya, karena faktor lama bekerja. Berdasarkan data subjek penelitian, terdapat 33 perawat (44 persen) yang lama bekerjanya lebih dari 20 tahun, 28 perawat (37,33 persen) yang lama kerjanya 10 sampai 20 tahun, dan 14 perawat (18,66 persen) yang lama kerjanya 1 sampai 10 tahun. Indriasari (2007) mengemukakan bahwa lamanya masa kerja perawat bekerja berhubungan dengan keanekaragaman pengalaman mereka dalam bekerja. Carmel (Indriasari, 2007) menyatakan bahwa karakteristik yang menjadi korban kekerasan pasien adalah mereka yang memiliki sedikit pengalaman dalam bekerja. Perawat pasien penyakit jiwa yang mempunyai banyak pengalaman kerja lebih mampu untuk mengontrol emosi dan mampu 
menguasai keadaan ketika berinteraksi langsung dengan pasien penyakit jiwa, sehingga dapat dikatakan bahwa semakin lama perawat pasien penyakit jiwa bekerja, maka semakin rendah perilaku agresifnya.

Munculnya perilaku agresi berkaitan dengan rasa marah yang terjadi dalam diri seseorang (Nashori, 2008). Rasa marah dapat muncul dengan sebab-sebab: (1) adanya serangan orang lain; dan (2) terjadinya frustasi dalam diri seseorang. Pertama, amarah akibat dari serangan atau gangguan yang dilakukan orang lain, dalam hal ini dilakukan oleh pasien penyakit jiwa. Menurut penelitian di Inggris, "Violence In Mental Health Care: The Experience Of Mental Health Nurses and Psychiatrist" menunjukkan bahwa perawat pasien penyakit jiwa lebih signifikan menerima kekerasan pasien penyakit jiwa daripada psikiater (Indriasari, 2007, h.109). Seorang perawat pasien penyakit jiwa rentan menerima kekerasan dari pasien karena kondisi mentalnya pasien penyakit jiwa yang labil. Perawat pasien penyakit jiwa dituntut untuk selalu siap siaga menghadapi berbagai perilaku pasien penyakit jiwa. Keadaan yang penuh tekanan dapat memungkinkan perawat pasien penyakit jiwa melakukan perilaku agresif. Indriasari (2007) mengemukakan bahwa seseorang dapat berperilaku agresif ketika mereka berada dalam kondisi diancam atau tak aman bagi mereka.

Kedua, karena terjadinya frustasi dalam diri seseorang. Frustasi adalah gangguan atau kegagalan dalam mencapai tujuan (Nashori, 2008). Seorang perawat pasien penyakit jiwa yang mempunyai harapan tinggi terhadap pasien penyakit jiwa akan frustasi ketika pasien penyakit jiwa tidak mampu memenuhi harapan itu. Dollars, dkk (Nashori, 2008) di Yale mengungkapkan bahwa frustasi selalu merupakan akibat dari frustasi. Munculnya perilaku agresif selalu mensyaratkan adanya frustasi, dan sebaliknya frustasi menimbulkan beberapa bentuk agresif.

Penelitian ini memiliki beberapa keterbatasan. Pertama, adanya fenomena social desirability yaitu kecenderungan subjek penelitian untuk mengisi jawaban sesuai dengan apa yang dianggapnya baik dan mencerminkan persetujuan norma sosial yang berlaku di sekitarnya, bukan jawaban yang mencerminkan sikap pribadi subjek yang sesungguhnya. Kedua, banyaknya aitem yang gugur dalam skala perilaku agresif yang disebabkan aitem yang dibuat kurang mampu mewakili indikator dalam variabel, sehingga kurangnya variasi jawaban yang dipilih subjek.

\section{Kesimpulan}

Hasil penelitian menunjukkan bahwa hipotesis yang diajukan diterima, yaitu ada hubungan negatif yang sangat signifikan antara sikap terhadap pasien dengan perilaku agresif pada perawat Rumah Sakit Jiwa Prof. dr. Soeroyo Magelang. Semakin positif sikap perawat terhadap pasien penyakit jiwa, maka semakin rendah perilaku agresifnya. Sebaliknya, semakin negatif sikap perawat terhadap pasien penyakit jiwa, maka semakin tinggi perilaku agresifnya.

Hasil penelitian ini memberikan sumbangan efektif sebesar 25,806 persen. Nilai tersebut memiliki arti bahwa sikap terhadap pasien penyakit jiwa dapat mempengaruhi perilaku agresif sebesar 25, 806 persen, sisanya 74,194 persen dipengaruhi oleh faktor lain diluar variabel yang digunakan dalam penelitian, misalnya faktor biologis, kognitif, amarah, dan frustasi. 
Berdasarkan hasil penelitian di atas, untuk menghindari perilaku agresif, sikap positif perlu ditanamkan pada setiap perawat terhadap pasiennya. Perawat yang mempunyai sikap positif terhadap pasien akan cenderung lebih peduli terhadap pasien serta memperlakukannya dengan lebih manusiawi.

Peneliti mengajukan saran bagi perawat pasien jiwa untuk mengikuti penyuluhanpenyuluhan atau pelatihan-pelatihan mengenai pengelolaan emosi untuk mengendalikan perilaku dalam menghadapi pasiennya. Pihak Rumah Sakit diharapkan memberi dukungan dengan sering mengadakan program yang berkaitan dengan pengelolaan emosi ketika menghadapi pasien penyakit jiwa serta mengenai pentingnya sikap positif terhadap pasien penyakit jiwa.

Peneliti lain yang berminat untuk meneliti perilaku agresif pada perawat disarankan untuk melibatkan variabel lain yang dipandang berpengaruh tetapi belum disertakan dalam penelitian ini, seperti tingkat pendidikan, kematangan emosi, dan lain-lain.

\section{Daftar Pustaka}

Abraham, C \& Shanley, E. 1997. Psikologi Sosial Untuk Perawat. Alih bahasa: Leoni Sally, M. Jakarta: Penerbit Buku Kedokteran.

Dayakisni, T dan Hudaniah. 2001. Psikologi Sosial. Malang

Diana, R. 2007. Agresivitas siswa SM A dan SM K Yogyakarta. Jurnal Psikologi Proyeksi. Vol. 2, no. 2. Semarang: Fakultas Psikologi Universitas Islam Sultan Agung

Indriasari, F, dkk. 2007. Hubungan Persepsi Kekerasan yang Dialami dengan Kecenderungan Perilaku Agresif pada Perawat Jiwa di RSJD Surakarta. Jurnal Kebidanan dan Keperawatan. Vol. 3. No 2. Yogyakarta.

Krahe, B. 2005. Perilaku Agresif. Yogyakarta: Pustaka Pelajar.

Nashori, F. 2008. Psikologi Sosial Islami. Bandung. Refika Aditama

Permanadeli, R. 1988. Studi Eksperimen Tentang Pengaruh Pesan Penjual Terhadap Sikap Positif pada Kosmetika Buatan Dalam Negeri. Jurnal Psikologi. No 1. Yogyakarta: Psikologi Universitas Gajah Mada.

Praditia, W. 2008. Problem Focused Coping pada Perawat di RSJ Ditinjau dari Kecerdasan Emosional. Skripsi. Universitas Katolik Soegijopranata Semarang. Tidak Diterbitkan.

Suryaningsih, W., Anggraini, R. 2006. Hubungan Kekerasan Orang tua Terhadap Anak Dengan Perilaku Agresif pada siswa SMP Negeri 2 Ungaran. Jurnal Psikologi Proyeksi, Vol. 1, No 1. Fakultas Psikologi Universitas Islam Sultan Agung Semarang. 
Hubungan antara Sikap Terhadap Pasien Penyakit Jiwa

dengan Perilaku Agresif Perawat Pasien Penyakit Jiwa

Proyeksi, Vol. 6 (1), 89-99

Syafrika, I dan Tommy Y. S. S. 2004. Persepsi Terhadap Lingkungan Fisik Kerja dan Dorongan Berperilaku Agresif pada Polisi Lalu Lintas. Jurnal Insan, vol. 6, no 3. Fakultas Psikologi Universitas Tarumanegara.

Walgito, B. 2001. Psikologi Sosial. Yogyakarta: Andi Offset. 